Jurnal Ilmiah

ILMU KOMPUTER

Universitas Udayana

Vol. XI, No. 1, April 2018

ISSN 1979 - 5661

\title{
APLIKASI GAMELAN CARUK BERBASIS MOBILE MENGGUNAKAN METODE SINTESIS SUARA MODIFIED FREQUENCY MODULATION
}

\author{
I Made Widiartha ${ }^{1}$, Anak Agung Istri Ngurah Eka Karyawati ${ }^{2}$ \\ Program Studi Teknik Informatika, Jurusan Ilmu Komputer \\ Fakultas Matematika dan Ilmu Pengetahuan Alam, Universitas Udayana \\ madewidiartha@unud.ac.id ${ }^{1}$,eka.karyawati@unud.ac.id²
}

\begin{abstract}
ABSTRAK
Gamelan caruk merupakan salah satu gamelan klasik khas bali yang sudah ada sejak abad ke15 dan dikategorikan sebagai gamelan tua (wayah). Gamelan ini sangat dibutuhkan dan memegang peranan penting dalam pelaksanaan upacara adat di bali khususnya upacara Dewa yadnya dan Pitra yadnya. Keberadaan gamelan caruk saat ini sudah sangatlah langka, para pemain gamelan ini umumnya sudah berusia lanjut. Seiring berjalannya waktu, banyaknya budaya asing yang masuk ke bali dan pola hidup era teknologi canggih saat ini telah berdampak pada menurunnya minat masyarakat bali utamanya generasi muda untuk berinteraksi dengan gamelan bali khususnya gamelan caruk ini.

Melihat keadaan ini tentunya sangat diperlukan sebuah langkah terobosan untuk melestarikan dan meningkatkan minat generasi muda bali terhadap gamelan tradisional khususnya gamelan caruk. Salah satu strategi yang dapat dilakukan sebagai upaya pelestarian gamelan tradisional bali adalah dengan melakukan digitalisasi perangkat gamelan caruk dan membangun aplikasi perangkat lunak gamelan dalam media berbasis mobile. Dengan adanya aplikasi mobile ini diharapkan dapat menjadi jembatan untuk generasi muda dalam mengenal dan membangkitkan daya tarik generasi muda pada gamelan tradisional bali. Perkembangan teknologi saat ini telah mampu untuk mendigitalisasi suara instrumen dan merepresentasikannya kedalam aplikasi perangkat lunak. Untuk dapat membangkitkan suara gamelan caruk ke dalam bentuk digital dapat digunakan teknik sintesis suara yaitu Modified frequency modulation (ModFM).

Dalam penelitian ini telah berhasil dibangun aplikasi gamelan caruk berbasis mobile dengan memanfaatkan suara hasil sintesis dengan penerapan metode ModFM. Dari hasil penelitian didapatkan bahwa suara terbaik hasil sintesis ini didapat melalui perbandingan frekuensi sinyal pembawa dan pemodulasi adalah 1:7. Suara hasil sintesis telah memiliki nada yang sama dengan suara dataset yang dibuktikan dengan seluruh frekuensi dasar suara hasil sintesis berada pada rentang toleransi frekuensi dasar masing-masing bilah.
\end{abstract}

Kata kunci: gamelan caruk, frequency modulation, sintesis suara

\section{Pendahuluan}

Provinsi Bali merupakan salah satu daerah di nusantara yang terkenal dengan kekayaan kesenian dan budayanya. Seni dan budaya merupakan dua hal yang sudah menjadi elemen dalam keseharian kehidupan masyarakat bali. Pola kehidupan ini telah 
melahirkan berbagai macam hal mulai dari alat musik khas daerah, tarian, pakaian adat, rumah adat, kerajinan khas, sampai pada adat budaya. Kehidupan masyarakat Bali tidak terlepas dengan yang namanya upacara yadnya.

Gamelan caruk merupakan salah satu gamelan klasik khas bali yang sudah ada sejak abad ke-15 dan dikategorikan sebagai gamelan tua (wayah). Gamelan ini sangat dibutuhkan dan memegang peranan penting dalam pelaksanaan upacara adat di bali khususnya upacara Dewa yadnya dan Pitra yadnya. Keberadaan gamelan caruk saat ini sudah sangatlah langka, para pemain gamelan ini umumnya sudah berusia lanjut. Seiring berjalannya waktu, banyaknya budaya asing yang masuk ke bali dan pola hidup era teknologi canggih saat ini telah berdampak pada menurunnya minat masyarakat bali utamanya generasi muda untuk berinteraksi dengan gamelan bali khususnya gamelan caruk ini. Generasi muda saat ini lebih cenderung menyukai perangkat-perangkat teknologi yang saat ini ada, begitu pula dengan alat musik yang dimainkan lebih banyak merupakan alat musik modern yang sarat akan muatan elektronik dan piranti lunak.

Melihat keadaan ini tentunya sangat diperlukan sebuah langkah terobosan untuk melestarikan dan meningkatkan minat generasi muda bali terhadap gamelan tradisional khususnya gamelan caruk. Salah satu strategi yang dapat dilakukan sebagai upaya pelestarian gamelan tradisional bali ditengah era modern saat ini adalah dengan melakukan digitalisasi perangkat gamelan dalam hal ini caruk dan membangun aplikasi perangkat lunak gamelan dalam media berbasis mobile. Dengan adanya aplikasi mobile ini diharapkan dapat menjadi jembatan untuk generasi muda dalam mengenal dan membangkitkan daya tarik generasi muda pada gamelan tradisional bali. Perkembangan teknologi saat ini telah mampu untuk mendigitalisasi suara instrumen merepresen tasikannya kedalam aplikasi perangkat lunak. Dalam membangkitkan suara gamelan caruk ke dalam bentuk digital dapat digunakan suatu teknik sintesis suara yaitu frequency modulation. Sintesis merupakan teknik yang digunakan untuk membangkitkan suara tertentu ke dalam bentuk digital. Salah satu metode sintesis yang memiliki performa unggul adalah Frequency Modulation (FM) seperti yang dihasilkan pada penelitian Lazzarini [3]. ModFM memiliki kelebihan mengkonsumsi ruang penyimpanan sedikit, memiliki ketelitian suara yang sangat baik karena menggunakan matematika murni, dan sangat baik untuk suara yang memiliki banyak variasi [1]. Disamping itu frequency modulation juga memiliki kemampuan menghasilkan spektrum yang kompleks dengan teknik yang sederhana [2].

Dengan memperhatikan performa dari metode FM, maka dalam penelitian ini dibangun sebuah aplikasi gamelan caruk berbasis mobile. Inputan dasar aplikasi ini adalah suara gamelan caruk yang didapat dari hasil sintesis suara dengan penerapan metode FM. Perangkat ini diharapkan mampu untuk menjadi media dalam upaya pelestarian budaya bali dalam hal ini gamelan tradisional caruk

\section{Landasan Teori}

\subsection{Gamelan Caruk}

Gambelan caruk termasuk jenis gamelan langka dan sakral yang didominasi oleh alatalat berbentuk bilahan yang terdiri dari dua buah gambang berukuran kecil dan dua buah saron.

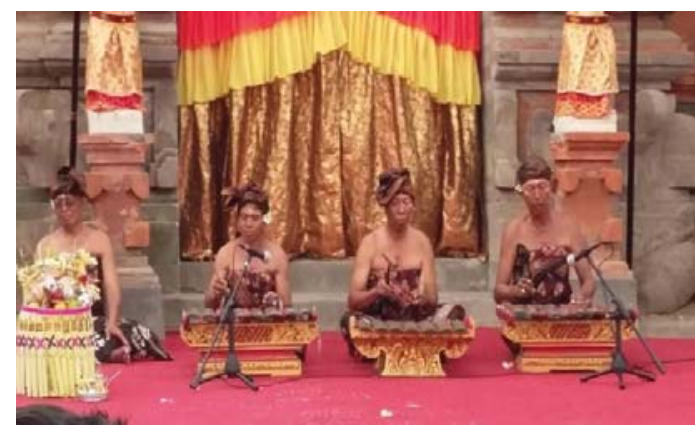

Gambar 1. Gamelan Caruk

Jenis gamelan ini biasanya dimainkan saat upacara yang erat kaitannya dengan Pitra 
Yadnya dan Dewa Yadnya. Saat ini gamelan caruk sudah semakin langka, keberadaan gamelan ini masih dapat ditemui di beberapa kabupaten seperti Karangasem, Gianyar, Tabanan, dan Badung. Gambar 1 memperlihatkan Penabuh sedang memainkan gamelan caruk.

\subsection{Frekuensi Dasar dan Frekuensi Harmoni}

Perlu diketahui bawa sinyal yang sebenarnya tidak berupa gelombang sinus. Sinyal asli memiliki berbagai frekuensi, amplitude yang berbeda, dan gangguan. Frekuensi yang dimiliki suatu sinyal ada dua, yaitu frekuensi dasar dan frekuensi harmoni. Frekuensi dasar merupakan frekuensi terendah dari suatu gelombang sinyal periodic. Sedangkan frekuensi harmoni adalah komponen frekuensi dari sinyal yang merupakan kelipatan dari frekuensi dasar [3]. Sebagai contoh dari frekuensi dasar dan frekuensi harmoni dari suatu sinyal diperlihatkan pada Gambar 2.

Dari Gambar 2 terdapat puncak pada frekuensi $330 \mathrm{~Hz}, 660 \mathrm{~Hz}, 990 \mathrm{~Hz}, 1320 \mathrm{~Hz}$, dan $1620 \mathrm{~Hz}$. Dapat dilihat bahwa nilai-nilai tersebut merupakan kelipatan dari puncak frekuensi pertama, yaitu $330 \mathrm{~Hz}$. Frekuensi $330 \mathrm{~Hz}$ dinamakan frekuensi dasar dan sekaligus sebagai harmoni pertama. Untuk frekuensi $660 \mathrm{~Hz}$ merupakan harmoni kedua dan merupakan overtone pertama dari frekuensi dasar. Overtone merupakan frekuensi yang lebih tinggi dari frekuensi dasar dan memiliki nilai kelipatan frekuensi dasar.

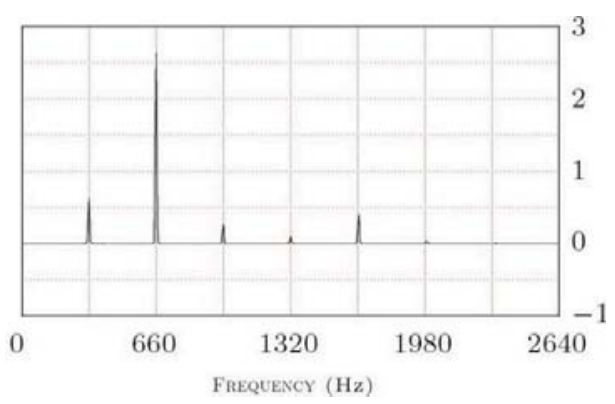

Gambar 2. Domain Frekuensi Sinyal Suara Piano Note E4

\subsection{Cent}

Cent adalah unit logaritmik ukuran yang digunakan untuk interval musik. Teknik pengukuran ini dikemukakan oleh Alexander J.Ellis (Ellis, 1885). Seperti relasi desibel untuk intensitas, cent adalah rasio antara dua frekuensi dekat. Jika diketahui frekuensi a dan b dari dua nada, nilai cent (n) untuk mengukur dari a hingga $b$ dapat dihitung dengan menggunakan formula 1 .

$n=1200 \cdot \log _{2}\left(\frac{b}{a}\right)$

\subsection{Transformasi Hilbert}

Transformasi Hilbert merupakan teknik yang kuat (Ronald L. Allen, 2004) yang dapat digunakan untuk mencari bungkus (envelope) dari sebuah sinyal. Untuk melakukan transformasi Hilbert dapat menggunakan persamaan 2 .

$x_{H}(t)=\frac{1}{\pi t} * x(t)$

Dimana $x_{H}$ merupakan sinyal hasil transformasi Hilbert, $x$ sinyal suara asli, dan $t$ adalah waktu.

\subsection{Sintesis}

Sintesis merupakan sebuah strategi atau teknik untuk membangkitkan suatu suara dengan menggunakan suatu parameter untuk mengontrol suara yang dibangkitkan.

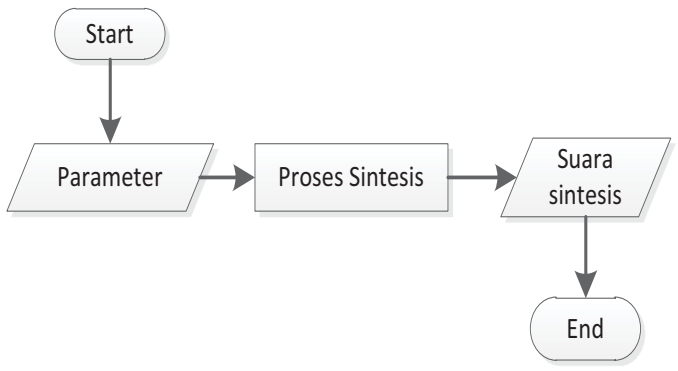

Gambar 3. Alur proses sintesis suara secara umum

Gambar 3 menunjukkan proses secara umum dari teknik sintesis suara. Parameter 
yang biasa digunakan adalah bungkus sinyal dan frekuensi dasar dari suatu suara yang ingin disintesis. Suara yang dihasilkan adalah suara sintesis berdasarkan parameter yang telah ditentukan dan dapat didengarkan.

\subsection{Modified Frequency Modulation (ModFM)}

ModFM merupakan metode perbaikan dari metode Frequency Modulation. ModFM dikemukakan oleh Victor lazzarini dan Joseph Timoney pada tahun 2010. Metode FM dimodifikasi dengan melakukan normalisasi pada fungsi Bessel dan menghasilkan persamaan ModFM yang diperlihatkan pada persamaan 3 .

$s(t)=\frac{A}{\varepsilon^{k}} \sum_{n=-\infty}^{\infty} I_{n}(k) \cos \left(\omega_{c} t+n \omega_{m} t\right)$

Keterangan :

$\mathrm{s}(\mathrm{t})$ : sinyal yang telah termodulasi

A : sinyal envelope

I : fungsi bessel yang telah ternormasilasi

$$
\begin{array}{ll} 
& \left(\mathrm{I}_{\mathrm{n}}(\mathrm{k}) \approx \frac{\mathrm{e}^{\mathrm{k}}}{\sqrt{2 \pi \mathrm{k}}}\right) \\
\mathrm{k} \quad: \text { indeks modulasi }
\end{array}
$$

\section{Alur Proses Sintesis}

Gambar 4 menunjukkan alur proses dari analisis hingga sintesis suara menggunakan metode ModFM. Pada bagan terlihat bahwa inputan dalam sistem ini adalah suara rekaman Caruk yang telah didapatkan sebelumnya.

Proses tahap pertama adalah melakukan analisis frekuensi dasar suara rekaman menggunakan program Sound Forge. Kemudian dilanjutkan pencarian sinyal envelope menggunakan transformasi Hilbert dan moving average filter. Langkah terakhir adalah proses sintesis menggunakan metode ModFM

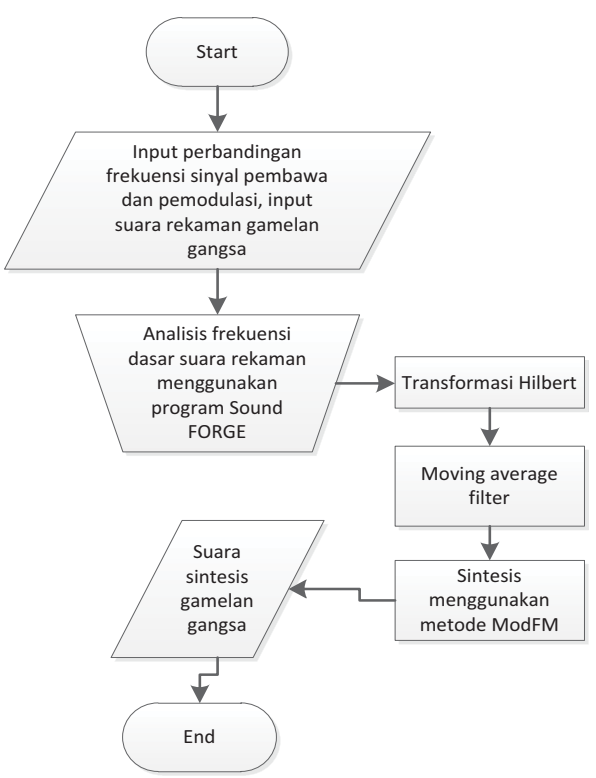

Gambar 4. Alur proses analisis hingga sintesis suara menggunakan metode ModFM.

\section{Hasil dan Pembahasan}

\subsection{Frekuensi Dasar Gamelan Caruk}

Untuk mendapatkan rentang dari frekuensi dasar gamelan Caruk, dikumpulkan data suara gamelan Caruk sebanyak 22 suara dengan jumlah suara berasal dari 3 perangkat gamelan Caruk yang berbeda. Dari pengolahan awal menggunakan program Sound Forge 10.0 didapatkan frekuensi tertinggi dari masing suara bilah. Dengan pendekatan overtone, didapatkan frekuensi dasar dari gamelan Caruk terletak pada rentang frekuensi seperti yang ditunjukkan pada Tabel 1, 2, dan 3.

Tabel 1. Rentang dan Rata-Rata Frekuensi Dasar Bilah Saron Besar

\begin{tabular}{cccc}
\hline Bilah & $\begin{array}{c}\text { Min } \\
(\mathbf{H z})\end{array}$ & Max $(\mathbf{H z})$ & $\begin{array}{c}\text { Rata- } \\
\text { rata }\end{array}$ \\
\hline 1 & 54.75 & 55.63 & 55.13 \\
2 & 49.75 & 49.75 & 49.75 \\
3 & 43.75 & 44.13 & 44.00 \\
4 & 40.63 & 40.75 & 40.71 \\
5 & 37.50 & 37.63 & 37.58 \\
6 & 213.75 & 213.88 & 213.83 \\
7 & 60.00 & 60.00 & 60.00 \\
\hline
\end{tabular}


Nilai rata-rata frekuensi dasar bilah digunakan untuk masukan pada proses sintesis. Dari sisi hasil dari analisis domain waktu menggunakan program Sound Forge 10 didapatkan frekuensi tertinggi dari ke-11 suara bilah ditunjukkan pada Tabel 2

Tabel 2. Rentang dan Rata-Rata Frekuensi Dasar Bilah Saron Kecil

\begin{tabular}{cccc}
\hline Bilah & $\begin{array}{c}\text { Min } \\
(\mathbf{H z})\end{array}$ & Max $(\mathbf{H z})$ & $\begin{array}{c}\text { Rata- } \\
\text { rata }\end{array}$ \\
\hline 1 & 108.38 & 108.50 & 108.46 \\
2 & 98.75 & 99.00 & 98.92 \\
3 & 87.88 & 89.38 & 88.58 \\
4 & 80.63 & 80.75 & 80.71 \\
5 & 74.75 & 74.75 & 74.75 \\
6 & 68.50 & 68.50 & 68.50 \\
7 & 120.13 & 120.25 & 120.17 \\
\hline
\end{tabular}

Tabel 3. Rentang dan Rata-Rata Frekuensi Dasar Bilah Gambang

\begin{tabular}{cccc}
\hline Bilah & $\begin{array}{c}\text { Min } \\
(\mathbf{H z})\end{array}$ & Max $(\mathbf{H z})$ & $\begin{array}{c}\text { Rata- } \\
\text { rata }\end{array}$ \\
\hline 1 & 42.75 & 43.00 & 42.83 \\
2 & 96.38 & 97.25 & 96.83 \\
3 & 26.25 & 32.13 & 28.46 \\
4 & 160.38 & 160.63 & 160.50 \\
5 & 50.25 & 51.25 & 50.79 \\
6 & 230.50 & 230.63 & 230.58 \\
7 & 67.63 & 67.88 & 67.79 \\
8 & 268.88 & 269.13 & 269.04 \\
\hline
\end{tabular}

\section{Input Proses Sintesis}

Selain rata-rata frekuensi dasar dan tertinggi pada tabel 1 sampai 3 , input proses sintesis berikutnya adalah rasio frekuensi sinyal carrier dan pemodulasi. Perbandingan yang digunakan adalah kombinasi nilai sinyal carrier dan sinyal pemodulasi diantara nilai bilangan bulat antara 1 sampai 9 .

Input lainnya adalah sinyal envelope. Sinyal envelope yang digunakan dalam proses sintesis adalah sinyal envelope dari dataset yang memiliki selisih frekuensi dasar terendah dengan frekuensi rata-rata untuk masingmasing bilah. Envelope yang dipilih diperlihatkan pada Tabel 4, 5, dan 6

Tabel 4. Dataset untuk ekstraksi sinyal envelope Saron Besar

\begin{tabular}{|l|l|l|l|l|l|l|l|}
\hline Bilah & 1 & 2 & 3 & 4 & 5 & 6 & 7 \\
\hline Dataset & 2 & 1 & 1 & 1 & 1 & 1 & 1 \\
\hline
\end{tabular}

Tabel 5. Dataset untuk ekstraksi sinyal envelope Saron Kecil

\begin{tabular}{|l|l|l|l|l|l|l|l|}
\hline Bilah & 1 & 2 & 3 & 4 & 5 & 6 & 7 \\
\hline Dataset & 1 & 1 & 3 & 2 & 1 & 1 & 2 \\
\hline
\end{tabular}

Tabel 6. Dataset untuk ekstraksi sinyal envelope Saron Gambang

\begin{tabular}{|l|l|l|l|l|l|l|l|l|}
\hline Bilah & 1 & 2 & 3 & 4 & 5 & 6 & 7 & 8 \\
\hline Dataset & 1 & 1 & 2 & 1 & 3 & 2 & 1 & 1 \\
\hline
\end{tabular}

\section{Uji Coba dan Evaluasi}

Uji coba dilakukan dengan dua kali skenario. Percobaan pertama dan kedua dilakukan menggunakan seluruh bilah yang ada pada gamelan Caruk. Skenario pertama dengan menghitung rata-rata selisih frekuensi harmoni dataset dengan suara hasil sintesis. Skenario kedua adalah melihat frekuensi dasar hasil sintesis berada pada rentang toleransi atau tidak. Tabel 7 memperlihatkan rata-rata selisih frekuensi dasar untuk seluruh percobaan. Dari hasil penelitian didapatkan perbandingan terbaik frekuensi sinyal carrier dan pemodulasi yang didapat adalah 1:7 untuk seluruh bilah.

Tabel 7. Selisih Frekuensi Dasar Bilah yang

Dipakai dengan Frekuensi Rata-rata dari

Seluruh Dataset

\begin{tabular}{|c|c|c|c|}
\hline Bilah & $\begin{array}{c}\text { Saron } \\
\text { Besar }\end{array}$ & $\begin{array}{c}\text { Saron } \\
\text { Kecil }\end{array}$ & Gambang \\
\hline 1 & 0.13 & 0.04 & 0.08 \\
\hline 2 & 0.00 & 0.08 & 0.04 \\
\hline 3 & 0.13 & 0.08 & 1.46 \\
\hline 4 & 0.04 & 0.04 & 0.00 \\
\hline
\end{tabular}




\begin{tabular}{|l|l|l|l|}
\hline 5 & 0.04 & 0.00 & 0.08 \\
\hline 6 & 0.04 & 0.00 & 0.04 \\
\hline 7 & 0.00 & 0.04 & 0.08 \\
\hline 8 & & & 0.08 \\
\hline
\end{tabular}

Dari hasil sintesis, frekuensi dasar yang dihasilkan dari perbandingan terbaik ini diperlihatkan pada Tabel 8.

Tabel 8. Frekuensi dasar suara hasil sintesis Caruk

\begin{tabular}{|c|c|c|c|}
\hline Bilah & $\begin{array}{c}\text { Saron } \\
\text { Besar }\end{array}$ & $\begin{array}{c}\text { Saron } \\
\text { Kecil }\end{array}$ & Gambang \\
\hline 1 & 55.63 & 108,38 & 43 \\
\hline 2 & 49,75 & 98,88 & 97,25 \\
\hline 3 & 44,125 & 88,63 & 31,75 \\
\hline 4 & 40,75 & 80,75 & 160,5 \\
\hline 5 & 37,625 & 74,75 & 51 \\
\hline 6 & 213,88 & 68,5 & 230,63 \\
\hline 7 & 60 & 120,25 & 67,75 \\
\hline 8 & & & 269,13 \\
\hline
\end{tabular}

Dari tabel dapat diamati bahwa nilai frekuensi dasar suara hasil sintesis dengan perbandingan terbaik telah berada pada rentang yang diperlihatkan pada tabel 1,2, dan 3. Dari hasil penelitian ini yaitu frekuensi dasar dan rasio terbaik selanjutnya diimplementasikan pada perangkat aplikasi mobile.

Setelah proses sintesis selesai dilakukan maka hasil sintesis ini disajikan dalam sebuah user interface. Dalam user interface ini suara masing-masing bilah dibagi kedalam beberapa tombol.

Aplikasi Caruk ini dibuat dengan didasari oleh hasil penelitian bahwa perbandingan terbaik frekuensi sinyal pembawa dan pemodulasi yang didapatkan untuk seluruh bilah adalah 1:7. Perbandingan ini telah membuat suara Caruk relatif sama dengan suara dataset aslinya. Selisih frekuensi dasar hasil sintesis dengan suara dataset yang ditiru terletak dari 0 hingga 3.51. Gambar 5, 6, dan 7 memperlihatkan grafik perbandingan antara nilai dataset dengan nilai yang dihasilkan dari proses sintesis.

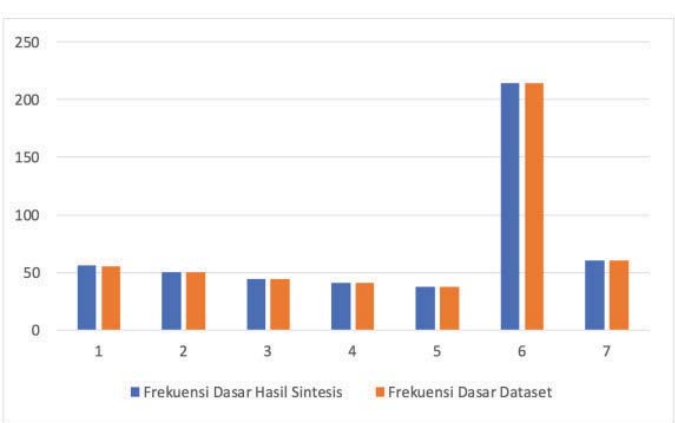

Gambar 5. Grafik Perbandingan Frekuensi Dasar Hasil Sintesis dengan Dataset Saron Besar

Dari gambar diperlihatkan bahwa terdapat perbedaan yang sangat kecil antara frekuensi dasar yang dihasilkan suara hasil sintesis dengan dataset. Begitu juga halnya dengan frekuensi tertinggi yang dihasilkan juga sangat kecil.

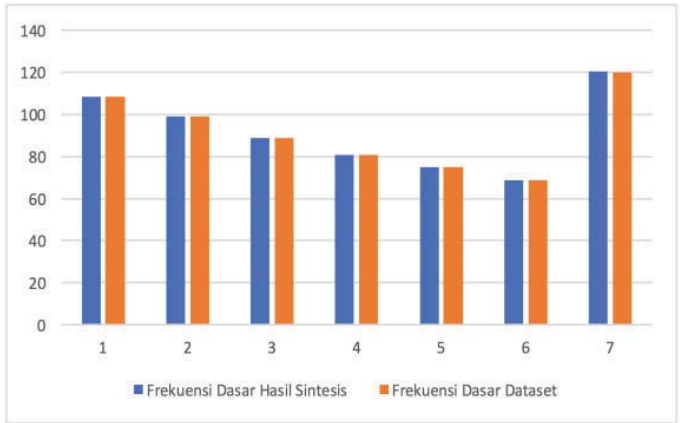

Gambar 6 : Grafik Perbandingan Frekuensi Dasar Hasil Sintesis dengan Dataset Saron Kecil

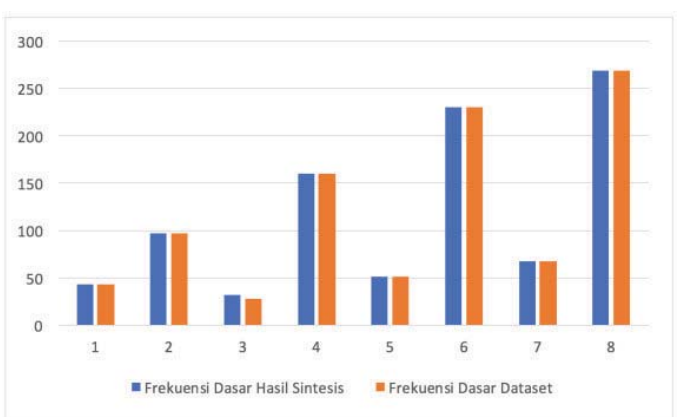

Gambar 7. Grafik Perbandingan Frekuensi Dasar Hasil Sintesis dengan Dataset Gambang 


\section{Perangkat Caruk Berbasis Mobile}

Antar muka aplikasi gamelan caruk yang telah dibangun dapat dilihat seperti pada Gambar 8 sampai dengan Gambar 10.

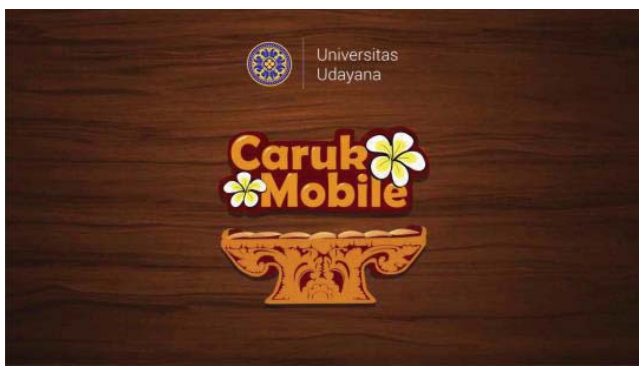

Gambar 8. Splash Screen Aplikasi

Pada Gambar 10 dapat dilihat tampilan awal/splash screen dari aplikasi ini, Setelah beberapa saat maka menu untuk memainkan aplikasi gamelan caruk ini ditampilkan seperti yang dapat diihat pada Gambar 9 pada sisi kiri gambar.

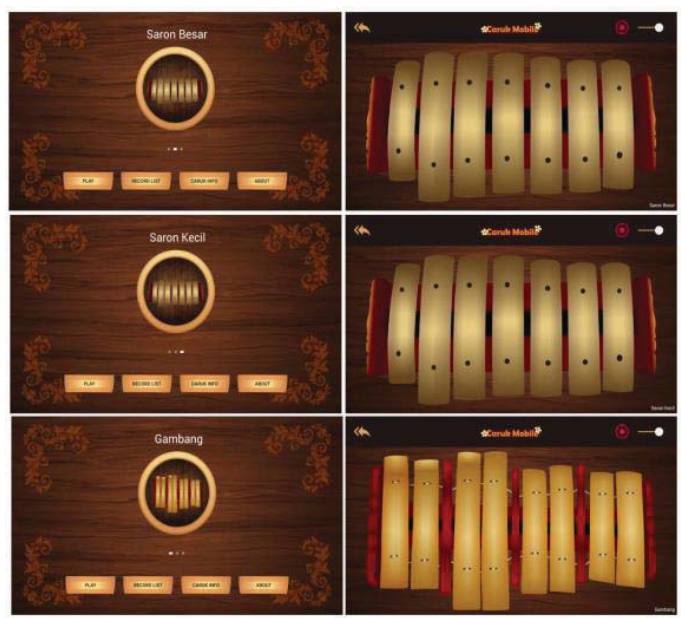

Gambar 9. Antarmuka Perangkat Gamelan

Caruk (Saron Besar, Saron Kecil, dan Gambang)

Terdapat empat buah menu diantaranya Play, Record List, Caruk Info, dan About. Pada menu Play disajikan gamelan caruk dimana pengguna dapat secara langsung memainkan gamelan caruk ini dengan cara menekan pada gambar gamelan yang disajikan di aplikasi. Ketiga jenis perangkat gamelan caruk ini dapat dilihat pada Gambar 9.
Dalam aplikasi gamelan caruk ini juga disediakan fasilitas untuk melakukan perekaman terhadap permainan gamelan yang telah dilakukan. Hal ini ditujukan agar pengguna memiliki file arsip terhadap permainan/kreasi yang telah dibuat. Adapun tampilan fitur perekaman ini dapat dilihat pada Gambar 10.

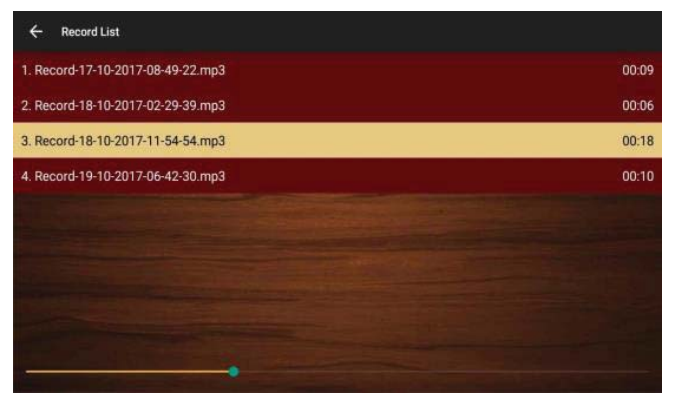

Gambar 10. Fitur Perekaman Permainan Caruk

\section{Kesimpulan}

Dari hasil uji coba dan evaluasi penelitian yang telah dilakukan dapat diambil kesimpulan sebagai berikut.

1. Aplikasi gamelan caruk berbasis mobile telah berhasil dibangun dengan menggunakan penerapan teknik Modified Frequency Modulation (ModFM) dalam mensintesa suara gamelan caruk.

2. Dari hasil sintesis dengan modFM didapatkan perbandingan terbaik frekuensi pembawa dan pemodulasi adalah 1:7. Perbandingan ini telah menghasilkan seluruh suara hasil sintesis gamelan caruk yang memiliki nada sama dengan suara dataset gamelan caruk. Hal ini dibuktikan dari seluruh data frekuensi dasar dan harmoni suara hasil sintesis berada pada rentang toleransi frekuensi dataset masing-masing bilah.

\section{Daftar Pustaka}

[1] Burk, P. (2004). Direct Synthesis versus Wavetable Synthesis. Mobileer. 
44 Jurnal Ilmu Komputer, Vol. XI, No. 1, April 2018, hlm 37-44

[2] Chowning, J. M. (1973). The Synthesis of Complex Audio Spectra by Means of Frequency Modulation. Stanford Artificial Intelligence Laboratory, 526.

[3] Lazzarini, V. T. (2010). Theory and Practice of Modified Frequency Modulation Synthesis. (p. 459). J. Audio Eng. Soc.

[4] Ronald L. Allen, D. W. (2004). Signal Analysis: Time, Frequency, Scale, and Structure. Institute of Electrical and Electronics Engineers 